Research Article

\title{
Cost-Effectiveness and Budget Impact Analyses of Pneumococcal Vaccination in Indonesia
}

\author{
Auliya A. Suwantika $\mathbb{D}^{1,2}$ Neily Zakiyah $\mathbb{D}^{1,2}$ Rizky Abdulah $\mathbb{D}^{1,2}$ Vensya Sitohang, \\ Gertrudis Tandy, ${ }^{3}$ Atiek Anartati, ${ }^{4}$ Tetrawindu Hidayatullah, ${ }^{4}$ Putri Herliana, \\ and Sri R. Hadinegoro ${ }^{5}$ \\ ${ }^{1}$ Department of Pharmacology and Clinical Pharmacy, Faculty of Pharmacy, Universitas Padjadjaran, \\ Bandung 45363, Indonesia \\ ${ }^{2}$ Center of Excellence in Higher Education for Pharmaceutical Care Innovation, Universitas Padjadjaran, \\ Bandung 45363, Indonesia \\ ${ }^{3}$ Directorate of Health Surveillance and Quarantine, Directorate General of Disease Prevention and Control, Ministry of Health, \\ Jakarta 12750, Indonesia \\ ${ }^{4}$ Clinton Health Access Initiative, Jakarta 10450, Indonesia \\ ${ }^{5}$ Department of Child Health, Faculty of Medicine, Universitas Indonesia, Jakarta 10440, Indonesia
}

Correspondence should be addressed to Auliya A. Suwantika; auliya@unpad.ac.id

Received 6 March 2020; Revised 9 April 2021; Accepted 17 April 2021; Published 27 April 2021

Academic Editor: Giuseppe La Torre

Copyright (C) 2021 Auliya A. Suwantika et al. This is an open access article distributed under the Creative Commons Attribution License, which permits unrestricted use, distribution, and reproduction in any medium, provided the original work is properly cited.

As a country with the high number of deaths due to pneumococcal disease, Indonesia has not yet included pneumococcal vaccination into the routine program. This study aimed to analyse the cost-effectiveness and the budget impact of pneumococcal vaccination in Indonesia by developing an age-structured cohort model. In a comparison with no vaccination, the use of two vaccines (PCV10 and PCV13) within two pricing scenarios (UNICEF and government contract price) was taken into account. To estimate the cost-effectiveness value, a 5-year time horizon was applied by extrapolating the outcome of the individual in the modelled cohort until 5 years of age with a 1-month analytical cycle. To estimate the affordability value, a 6-year period (2019-2024) was applied by considering the government's strategic plan on pneumococcal vaccination. In a comparison with no vaccination, the results showed that vaccination would reduce pneumococcal disease by 1,702,548 and 2,268,411 cases when using PCV10 and PCV13, respectively. Vaccination could potentially reduce the highest treatment cost from the payer perspective at \$53.6 million and \$71.4 million for PCV10 and PCV13, respectively. Applying the UNICEF price, the incremental cost-effectiveness ratio (ICER) from the healthcare perspective would be $\$ 218$ and $\$ 162$ per QALY-gained for PCV10 and PCV13, respectively. Applying the government contract price, the ICER would be $\$ 987$ and $\$ 747$ per QALY-gained for PCV10 and PCV13, respectively. The result confirmed that PCV13 was more cost-effective than PCV10 with both prices. In particular, introduction cost per child was estimated to be $\$ 0.91$ and vaccination cost of PCV13 per child ( 3 doses) was estimated to be $\$ 16.61$ and \$59.54 with UNICEF and government contract prices, respectively. Implementation of nationwide vaccination would require approximately $\$ 73.3-\$ 75.0$ million (13-14\% of routine immunization budget) and $\$ 257.4-\$ 263.5$ million (45-50\% of routine immunization budget) with UNICEF and government contract prices, respectively. Sensitivity analysis showed that vaccine efficacy, mortality rate, and vaccine price were the most influential parameters affecting the ICER. In conclusion, pneumococcal vaccination would be a highly cost-effective intervention to be implemented in Indonesia. Yet, applying PCV13 with UNICEF price would give the best cost-effectiveness and affordability values on the routine immunization budget. 


\section{Introduction}

Pneumococcal disease (PD) has been reported to be responsible for $16 \%$ of deaths in children under five years of age $[1,2]$. Streptococcus pneumoniae carriage is more prevalent in children than in adults, with the increasing trend in colonization rate observed from birth until the age of 1-2 years [3, 4]. In particular, the management complexity of invasive and noninvasive $\mathrm{PD}$ is associated with a relatively high clinical and economic burden due to PD from the healthcare, societal, and payer perspectives [5-7].

Several studies reported that vaccination was the most cost-effective intervention in reducing the incidence rate of $\mathrm{PD}$ [8]. In Asia, the children pneumococcal vaccination program was confirmed to be cost-effective and even cost saving in certain conditions [9]. The firstly developed pneumococcal conjugate vaccine (PCV), a 7-valent PCV (PCV7), has proven to reduce the incidence rate of $\mathrm{PD}$ significantly [8]. Nevertheless, the latest studies confirmed that the newer versions of PCV, a 10-valent PCV (PCV10) and a 13-valent PCV (PCV13), have more superior effectiveness, compared to PCV7 [10, 11]. Based on the evidence related to the effectiveness of $\mathrm{PCV}$, the World Health Organization (WHO) has initiated to encourage the implementation of pneumococcal vaccination in the national immunization programs (NIPs), specifically in countries with high prevalence of PD [12].

Despite the fact that the incidence rate of PD is concentrated in the Asia region [2, 13], only few countries in this region have introduced pneumococcal vaccination [14-16]. As one of the countries with the highest number of deaths due to PD in Asia, Indonesia has initiated to conduct a pilot study of pneumococcal vaccination in 2017 by focusing in two districts (East and West Lombok) with the highest prevalence of PD [17]. Nevertheless, a nationwide vaccination program has not been implemented. This situation might be caused by multiple factors, such as lack of economic evaluation studies that confirmed the cost-effectiveness and the affordability values of pneumococcal vaccination to be implemented in Indonesia.

Considering the high PD and the lack of comprehensive study on economic evaluation of pneumococcal vaccination in Indonesia, this study aimed to analyse the cost-effectiveness and the budget impact of pneumococcal vaccination in Indonesia.

\section{Methods}

2.1. Model. We developed an age-structured cohort that was based on a decision tree model. In a comparison with no vaccination, the use of two vaccines (PCV10 and PCV13) within two pricing scenarios (UNICEF and government contract price) was taken into account. To estimate the costeffectiveness value, a 5-year time horizon was used due to the significant effectiveness of both PCV10 and PCV13 in children under 5 years of age [18]. To estimate the impact of $\mathrm{PD}$, we extrapolated the outcome of the individual in the modelled cohort until five years of age with a 1-month analytical cycle (see Figure 1). In a 6-year period (2019-2024), the budget impact analysis was focused on by considering the government's strategic plan on pneumococcal vaccination. Several targeted regions were applied to introduce pneumococcal vaccine in Indonesia, which was based on the strategic plan of the Ministry of Health $(\mathrm{MoH})$ in 2019 (2 provinces: NTB and Bangka Belitung and 5 districts: Bogor, Bekasi, Surabaya, Gresik, and Sidoarjo); 2020 (5 provinces: NTB, Bangka Belitung, Jakarta, and West and East Java); and 2021-2023 (nationwide).

2.2. Disease Burden Estimates. Three levels of severity (outpatient, hospitalization, and fatal) were taken into account in the model by considering pneumococcal pneumonia (PP), nonbacteremic PP and invasive pneumococcal disease (IPD) [19]. To estimate the number of PP and IPD cases, we applied the incidence rate of PP and IPD in children under 5 years of age from studies by Walker et al. and O'Brien et al., respectively [20,21]. To estimate the number of fatal PD and IPD cases, we transformed the mortality rate of $\mathrm{PD}$ and applied the case fatality rate of IPD in children under 5 years of age from a study by O'Brien et al. and a progress report on committing to child survival by UNICEF, respectively $[21,22]$. To estimate the number of PP, nonbacteremic PP, and IPD cases in each level of severity, we considered the proportion of outpatient, hospitalization, and fatal cases in children under 5 years of age in Indonesia, according to local data [23-25].

2.3. Vaccine Effectiveness, Vaccination Schedule, and Vaccination Coverage. Direct effectiveness of PCV13 for prevention of PP (72.93\%) in Indonesia was derived from the observed effectiveness value of PCV13 in Malaysia (91.40\%) and adjusted for direct effectiveness of PCV13 in Indonesia by considering serotype coverage of PCV13 in Malaysia (75.20\%) and in Indonesia (60.00\%) [26-28]. In general, this is expressed as

$$
\text { VE PCV13 Indonesia }=\text { VE PCV } 13 \text { Malaysia } \times \frac{\text { Serotype Ccoverage }_{\text {PCV13 Indonesia }}}{\text { Serotype Ccoverage }_{\text {PCV13Malaysia }}}
$$

Direct effectiveness of PCV10 for prevention of PP (54.73\%) was adjusted from direct effectiveness of PCV13 by considering the proportion of direct effectiveness of PCV10 (68.60\%) and PCV13 (91.40\%) in Malaysia [24]. Regarding 


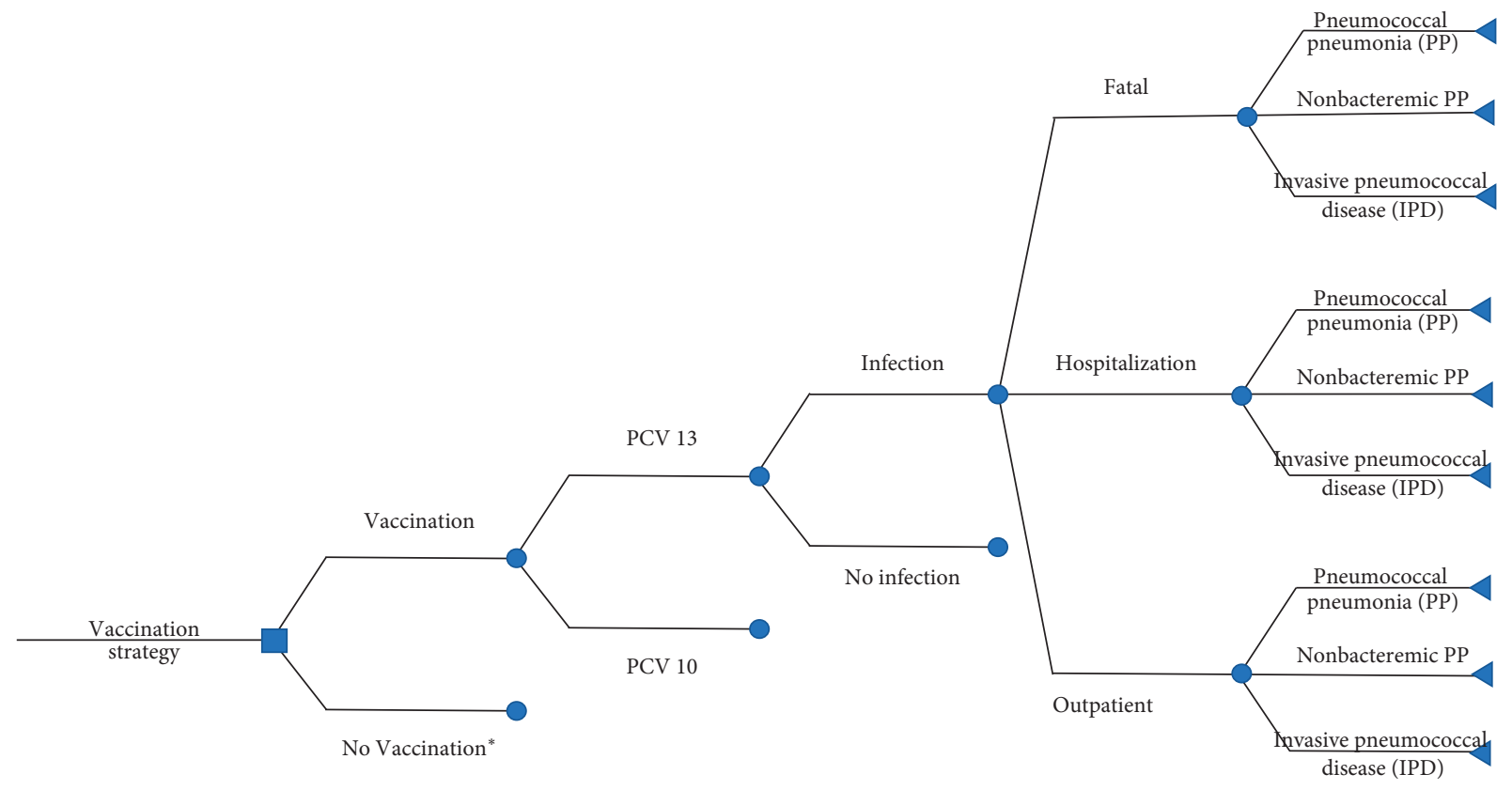

FIgURE 1: Decision analytic model.

direct effectiveness of PCV10 for prevention of IPD (59.90\%), it was derived from a study by Hirose et al. on epidemiological profile pre- and postintroduction of PCV10 [29]. The same approach on calculating direct effectiveness of PCV13 for prevention of PP was applied to estimate direct effectiveness of PCV13 for prevention of IPD (79.81\%). Direct effectiveness of PCV13 (18.02\%) and PCV 10 (13.52\%) for prevention of nonbacteremic PP was calculated by applying the proportion of direct effectiveness of PCV13 for prevention of PP (94.70\%) and nonbacteremic PP (23.40\%) in Japan [16]. Indirect effectiveness of PCV10 and PCV13 in all cases was not taken into account in this study.

Vaccination was scheduled at 2, 3, and 12 months of age, according to the recommendation of the Indonesian Technical Advisory Group on Immunization (ITAGI) on pneumococcal vaccination schedule [30]. Vaccination coverage was assumed to be $85 \%$ in 2019 and would increase 2.5\% annually until 2024 .

2.4. Outcome Measures. In the absence of available data on quality-adjusted life year (QALY) losses in Indonesia due to PD, we estimated the QALY losses in affected infants and children by considering the duration of illness at $1 ; 7.14$; 7.90; 14.6; and 365 days for all outpatient, nonbacteremic PP-hospitalized, PP-hospitalized, IPD-hospitalized, and fatal cases, respectively. Furthermore, disutility scores at 0.006 ; $0.008 ; 0.008 ; 0.023$; and 1 would be applied, consecutively $[16,31]$. All outcome measures were discounted at a $3 \%$ rate (see Table 1 ).

2.5. Treatment and Vaccination Costs. Cost analyses in this study were conducted from three perspectives: healthcare (direct medical costs), societal (direct and indirect costs), and payer. Healthcare costs (e.g., costs for detection, treatment, continuing care, rehabilitation, and terminal care) in all outpatient and hospitalized cases were observed from several primary healthcare centres in Kalimantan and two public hospitals in Lombok, respectively. For this study, we focused our analysis on total direct medical costs by considering the microcosting approach, which estimated treatment costs by summing all medical services that were received by an individual patient. Societal costs in all outpatient and hospitalized cases were obtained from two cost studies conducted in Indonesia by Walters et al. and Zhang et al., respectively $[32,34]$. To estimate total indirect costs, we considered travel, caregiver time, and uninsured healthcare costs borne by households for pneumonia [32]. Due to the lack of Indonesian data, healthcare and societal costs in IPD-hospitalized cases were derived from a study by Le at al. on the economic burden of pneumonia and meningitis among children less than 5 years of age in Hanoi, Vietnam [33]. To estimate total payer costs, we considered all costs covered by the Indonesian National Health Insurance System that was managed by BPJS Kesehatan. Total payer costs in outpatient, hospitalized, and IPD-hospitalized cases were directly observed from two districts in Lombok and adjusted for the national level by considering the tariff of Indonesia case-based groups (INA-CBGs) [35].

With respect to the vaccine price, UNICEF prices for PCV10 and PCV13 were estimated to be $\$ 3.30$ and $\$ 3.05$, respectively. Started in 2021 (nationwide vaccination), these values would decrease up to $\$ 2.95$ due to the use of singledose presentation instead of multidose presentation [36]. The government contract price for PCV13 was applied to be $\$ 18.90$, according to the agreement between the $\mathrm{MoH}$ with the vaccine manufacturer. The government contract price for PCV10 was assumed to be $\$ 17.45$ by considering the market prices of PCV13 and PCV10 in Indonesia. The vaccine administration cost was assumed to be $\$ 0.5$, and the 
TABle 1: Parameters used in the model.

\begin{tabular}{|c|c|c|}
\hline Parameters & Baseline value & Reference \\
\hline $\begin{array}{l}\text { Epidemiology } \\
\text { Incidence rate of PP (children }<5 \text { years of age) } \\
\text { Incidence rate of IPD (children }<5 \text { years of age) } \\
\text { Mortality rate of PP } \\
\text { Case fatality rate of IPD }\end{array}$ & $\begin{array}{c}0.26 \\
0.0045 \\
3.78 \text { per } 1,000 \text { live births } \\
0.57\end{array}$ & $\begin{array}{l}{[20]} \\
{[21]} \\
{[21]} \\
{[22]}\end{array}$ \\
\hline $\begin{array}{l}\text { Duration of illness (days) } \\
\text { IPD hospitalized } \\
\text { PP hospitalized } \\
\text { Nonbacteremic PP hospitalized } \\
\text { All outpatient cases }\end{array}$ & $\begin{array}{c}14.6 \\
7.9 \\
7.14 \\
1\end{array}$ & {$[16,26]$} \\
\hline $\begin{array}{l}\text { Utility losses } \\
\text { All outpatient cases } \\
\text { Nonbacteremic PP hospitalized } \\
\text { PP hospitalized } \\
\text { IPD hospitalized } \\
\text { All fatal cases }\end{array}$ & $\begin{array}{l}0.00002 \\
0.00016 \\
0.00017 \\
0.00092 \\
1.00000\end{array}$ & $\begin{array}{c}{[16,26] ;} \\
\text { Calculated }\end{array}$ \\
\hline $\begin{array}{l}\text { Introduction strategy } \\
\text { Vaccination coverage } \\
\text { Vaccination schedule } \\
\text { Vaccine efficacy } \\
\text { PP } \\
\text { IPD } \\
\text { Nonbacteremic PP }\end{array}$ & $\begin{array}{l}\text { 85\% (increase } 2.5 \% \text { annually) } \\
\text { 2-3-12 months } \\
\text { 54.73\% (PCV10); 72.93\% (PCV13) } \\
59.90 \% \text { (PCV10); 79.81\% (PCV13) } \\
13.52 \% \text { (PCV10); } 18.02 \% \text { (PCV13) }\end{array}$ & $\begin{array}{c}{[20]} \\
{[20]} \\
{[23-25]} \\
\text { Calculated }\end{array}$ \\
\hline $\begin{array}{l}\text { Healthcare cost* } \\
\text { Outpatient } \\
\text { Hospitalized } \\
\text { IPD hospitalized }\end{array}$ & $\begin{array}{l}\$ 0.63 \\
\$ 59 \\
\$ 334\end{array}$ & $\begin{array}{l}\text { Primary } \\
\text { Data } \\
\text { [29] }\end{array}$ \\
\hline $\begin{array}{l}\text { Societal cost** } \\
\text { Outpatient } \\
\text { Hospitalized } \\
\text { IPD hospitalized }\end{array}$ & $\begin{array}{c}\$ 2.65 \\
\$ 135.20 \\
\$ 810.00\end{array}$ & $\begin{array}{l}{[27]} \\
{[28]} \\
{[29]}\end{array}$ \\
\hline $\begin{array}{l}\text { Payer cost }{ }^{* * *} \\
\text { Outpatient } \\
\text { Hospitalized } \\
\text { IPD hospitalized }\end{array}$ & $\begin{array}{l}\$ 18.37 \\
\$ 288.22 \\
\$ 301.80 \\
\end{array}$ & $\begin{array}{c}\text { Reference [30]; } \\
\text { Adjusted }\end{array}$ \\
\hline $\begin{array}{l}\text { Vaccination cost } \\
\text { PCV13 (UNICEF price) } \\
\text { PCV10 (UNICEF price) } \\
\text { PCV13 (government contract price) } \\
\text { PCV10 (government contract price) } \\
\text { Waste disposal } \\
\text { Administration cost }\end{array}$ & $\begin{array}{c}\$ 3.30 \\
\$ 3.05 \\
\$ 18.90 \\
\$ 17.45 \\
25 \% \\
\$ 0.50\end{array}$ & $\begin{array}{c}{[31]} \\
{[31]} \\
\text { MoH } \\
\text { Assumed } \\
{[32]} \\
{[32]}\end{array}$ \\
\hline Discount rate & $3 \%$ & [33] \\
\hline
\end{tabular}

waste disposal cost was estimated to be $25 \%$, according to a previous study in Indonesia [37]. All cost items from different currencies and years were converted into 2019 US\$ by using purchasing power parity (PPP) [38]. All costs were also discounted with an annual rate of $3 \%$ (see Table 1 ).

2.6. ICER and Sensitivity Analyses. The incremental costeffectiveness ratio (ICER) was calculated in two different vaccines and pricing scenarios by dividing the difference in total cost (vaccination and treatment cost) with the difference in QALY losses. The ICER was evaluated by using the criteria on cost-effectiveness of universal immunization according to the threshold of GDP per capita: (i) highly costeffective (less than one GDP per capita); (ii) cost-effective (between 1 and 3 times GDP per capita); and (iii) costineffective (more than 3 times GDP per capita) [39]. Univariate sensitivity analysis was performed to investigate the effects of different input parameters on cost and health outcomes, by varying each parameter at a value of $\pm 25 \%$ while keeping other parameters constant.

2.7. Budget Impact Analysis. The most cost-effective PCV within 2 pricing strategies (UNICEF and government contract price) would be taken into account in the budget 
impact analysis by investigating the impact of pneumococcal vaccination in the national healthcare budget and routine immunization budget in a 6-year period of 2019-2024. The number of required vaccines was estimated by considering the number of targeted infants, required doses, and buffer stocks. For UNICEF vaccine price, additional costs were calculated by applying costs of tax, import duty, forwarder, and distribution. Next to vaccination costs, introduction cost was also estimated by considering introduction activities related to pneumococcal vaccination, such as information, education and communication (IEC), social mobilization, microplanning, training, supervision, and monitoring.

\section{Results}

Considering no vaccination as the major comparator and the strategic plan of the $\mathrm{MoH}$ on the targeted area of pneumococcal vaccination in a period of 2019-2024, we estimated that PCV10 vaccination would reduce PD by 29,917 ; 132,986; 373,987; 381,856; 388,540; and 395,532 cases, consecutively. In the same period, PCV13 vaccination would reduce $P D$ by 39,$860 ; 177,186 ; 498,286 ; 508,411 ; 517,676$; and 526,992 cases, consecutively. In total, PCV10 and PCV13 vaccination would potentially reduce $P D$ by $1,702,548$ and 2,268,411, respectively (see Figure 2(a)). Applying PCV10 vaccine, treatment cost would be reduced by $\$ 6.0$ million; $\$ 15.7$ million and \$53.6 million from the healthcare, societal, and payer perspectives, respectively. Applying PCV13 vaccine, treatment cost would be reduced by $\$ 8.0$ million; $\$ 21.0$ million; and $\$ 71.4$ million from all perspectives, respectively (see Figure (b)).

Applying UNICEF price, the total incremental cost (vaccination and treatment cost) for the implementation of PCV10 vaccination would be $\$ 255.9$ million; $\$ 246.3$ million; and $\$ 208.6$ million from the healthcare, societal, and payer perspectives, respectively. For the implementation of PCV13 vaccination, the total incremental cost would be $\$ 272.0$ million; \$259.1 million; and \$208.9 million from all perspectives, respectively. Applying government contract price, the total incremental cost for the implementation of PCV10 vaccination would be $\$ 1,172.4$ million; $\$ 1,162.8$ million; and $\$ 1,125.1$ million from the healthcare, societal, and payer perspectives, respectively. For the implementation of PCV13 vaccination, the total incremental cost would be $\$ 1,170.4$ million; \$1,157.6 million; and \$1,107.4 million from all perspectives, respectively. With respect to QALY losses, we estimated that PCV10 and PCV13 vaccination would save 1.2 million and 1.6 million discounted QALYs, respectively. The cost-effectiveness values of a nationwide vaccination program from all perspectives are shown in Figure 3(a). Applying PCV10 with UNICEF price, the ICERs would be \$218; \$210; and \$178 per QALY-gained from the healthcare, societal, and payer perspectives, respectively. Applying PCV13 with UNICEF price, the ICERs would be \$162; \$154; and $\$ 122$ per QALY-gained from all perspectives, respectively. Next to UNICEF price, applying PCV10 with government contract price, the ICERs would be \$987; \$979; and $\$ 948$ per QALY-gained from all perspectives, respectively.
Applying PCV13 with government contract price, the ICERs would be \$747; \$739; and \$707 per QALY-gained from all perspectives, respectively. Obviously, cost-effectiveness values with UNICEF price are much better than government contract price. Additionally, PCV13 is more cost-effective than PCV10 with all prices and perspectives. Considering the GDP per capita in Indonesia of US\$ 3,859 [40], the results confirmed that pneumococcal vaccination would be highly cost-effective under UNICEF and government market prices. The effects of varying input parameters on the ICERs are shown in a tornado chart in Figure 3(b). Using PCV13 with UNICEF price from the healthcare perspective as a reference case, the result confirmed that vaccine coverage, vaccine efficacy, mortality rate, and vaccine price are the most influential parameters affecting the cost-effectiveness value.

To introduce PCV13 vaccination in a 6-year period of 2019-2024, the government would require introduction cost (including cost of social mobilization/IEC, microplanning, training, supervision, and monitoring) at $\$ 0.2$ million; $\$ 0.7$ million; $\$ 4.2$ million; $\$ 4.2$ million; $\$ 4.2$ million; and $\$ 4.2$ million, consecutively. Introduction cost of PCV13 per child was estimated to be $\$ 0.91$. Vaccination cost of PCV13 per child (3 doses) was estimated to be $\$ 16.61$ and $\$ 59.54$ with UNICEF and government contract prices, respectively. In the context of making comparison between total vaccination cost of PCV13 with routine immunization budget in a 6-year time horizon, implementation of nationwide vaccination would require approximately \$257.4-\$263.5 million (45-50\% of routine immunization budget) and $\$ 73.3-\$ 75.0$ million (13-14\% of routine immunization budget) with government contract and UNICEF prices, respectively. Comparing with national healthcare budget, the total vaccination cost of PCV13 would be approximately 5\% and $2 \%$ of total health expenditure with both prices, respectively (see Table 2).

\section{Discussion}

Despite the fact that PD in Indonesia could be categorized as a high burden disease, vaccination appears to be one of the promising interventions to prevent pneumococcal infections, as this study confirmed that vaccination would be highly cost-effective with UNICEF and government contract prices, according to the threshold of GDP per capita. Obviously, this study also confirmed that PCV13 is more costeffective than PCV10 with both prices. Our finding that pneumococcal vaccine would be cost-effective to be introduced in countries with high burden PD is linear with several previous studies that specifically focused in the Asia region $[9,16,26,41-57]$. Another finding, which confirmed that PCV13 is more cost-effective to be implemented than PCV10, is also in line with other studies that compared the use of PCV10 and PCV13 [16, 26, 49, 53]. This finding warrants future attention on prioritizing the use of PCV13 due to its better cost-effectiveness value than PCV10, which might be caused by significant difference values on vaccine effectiveness between PCV10 and PCV13, as several studies highlighted $[16,26]$. In comparison with government 


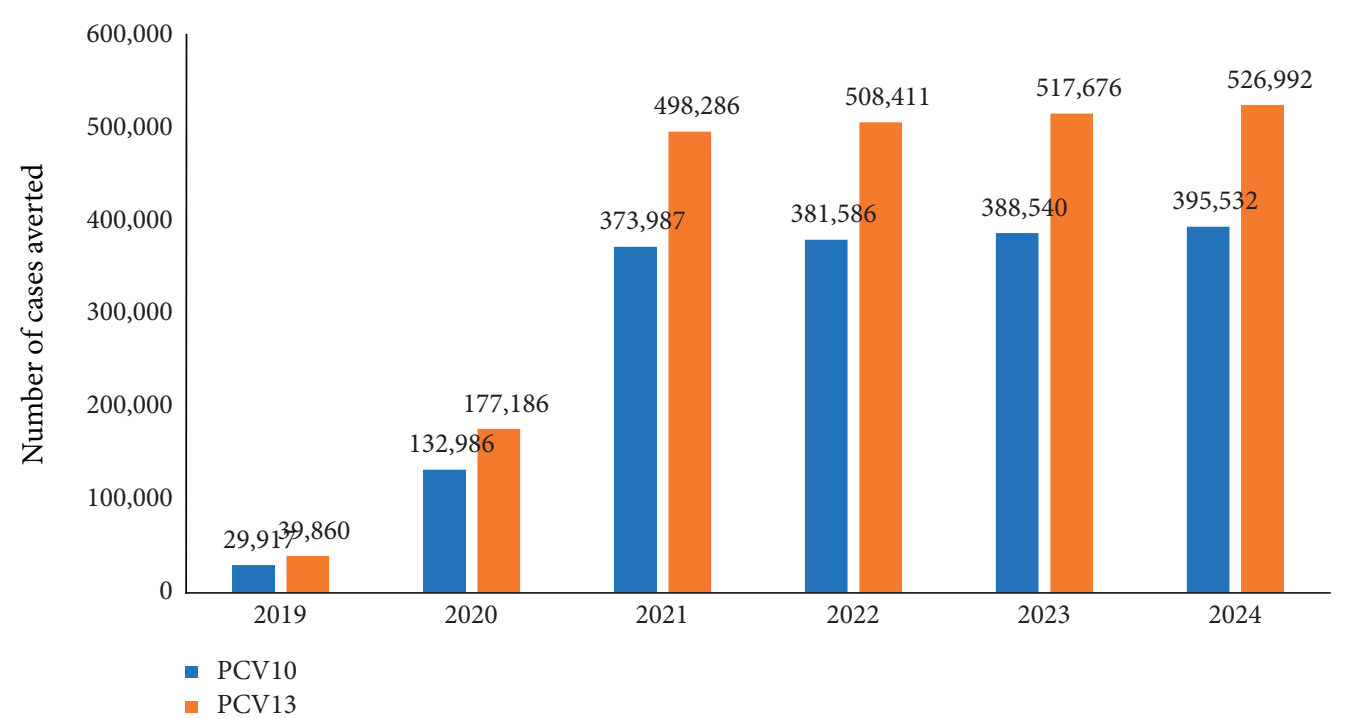

(a)

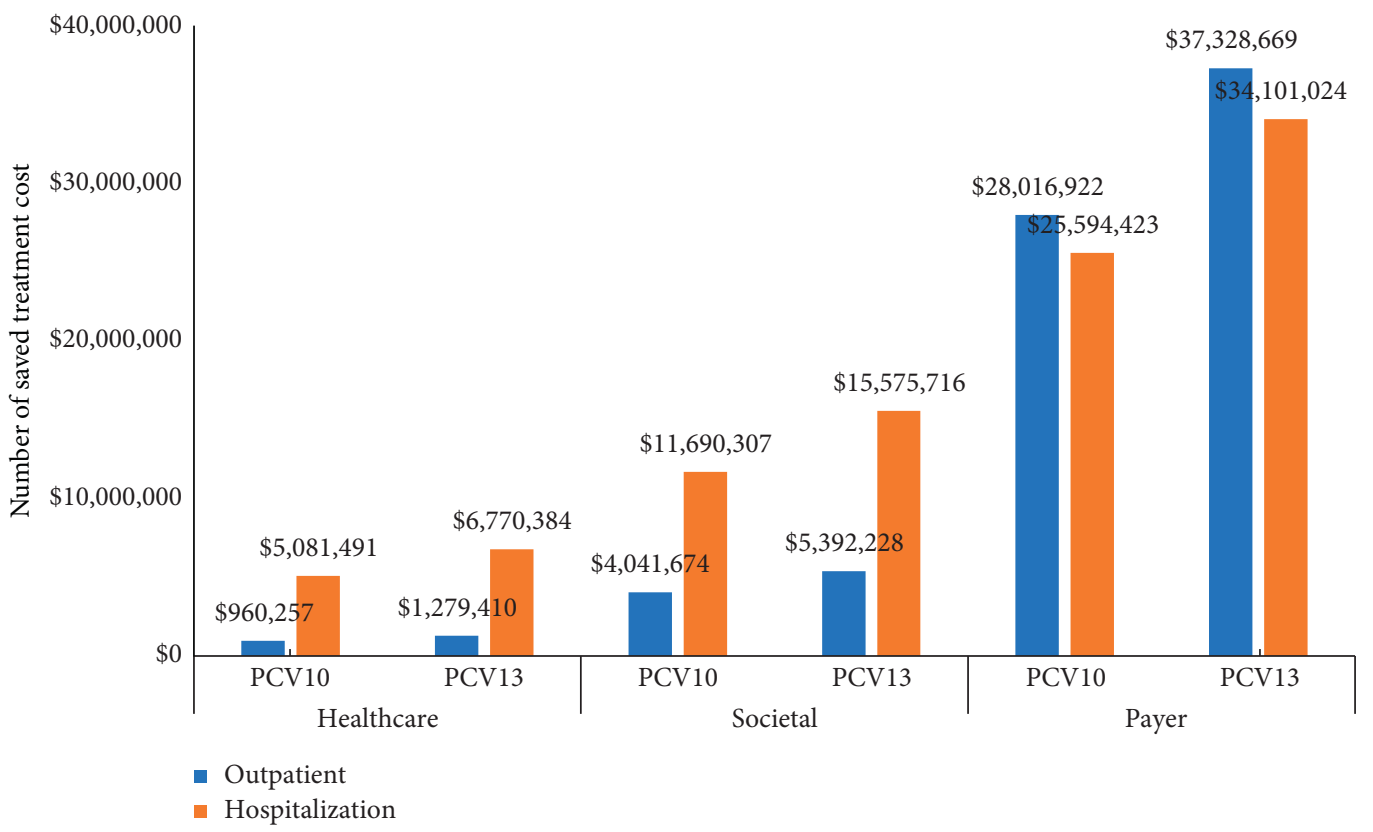

(b)

Figure 2: (a) Potential number of cases averted ( $<5$ years of age) through vaccination. (b) Cumulative number of saved treatment cost from all perspectives (2019-2024).

contract price, the implementation of PCV with UNICEF price would be more realistic to be implemented in Indonesia. Related to the sensitivity analyses, the results in this study reconfirmed the results from several previous studies that vaccine efficacy $[16,34,44,45,48,54]$, mortality rate $[26,50]$, and vaccine price $[43,50,52,54]$ are the most influential parameters affecting the cost-effectiveness value in the implementation of pneumococcal vaccination. However, the dominant role of these factors might lead the small difference between the ICERs from the healthcare, societal, and payer perspectives. Despite the fact that vaccination could potentially reduce the highest treatment cost from the payer perspective, the ICERs from this perspective confirmed the lowest value. It can be interpreted that the implementation of pneumococcal vaccination would yield the highest cost-effectiveness value from the payer perspective. Up to now, vaccination has not been covered by the National Health Security System. The result of this study illustrated the potential of pneumococcal vaccination to be included in the benefit package of national health insurance as one of the major strategies in preventing PD.

This study is not the first economic evaluation study on pneumococcal vaccination in Indonesia. Yet, it has several major novelties. Our study has some significant differences in the process of analysis. Firstly, in a comparison with no vaccination, the use of two vaccines (PCV13 and PCV10) within two different pricing scenarios (UNICEF and government contract prices) was taken into account, while a 


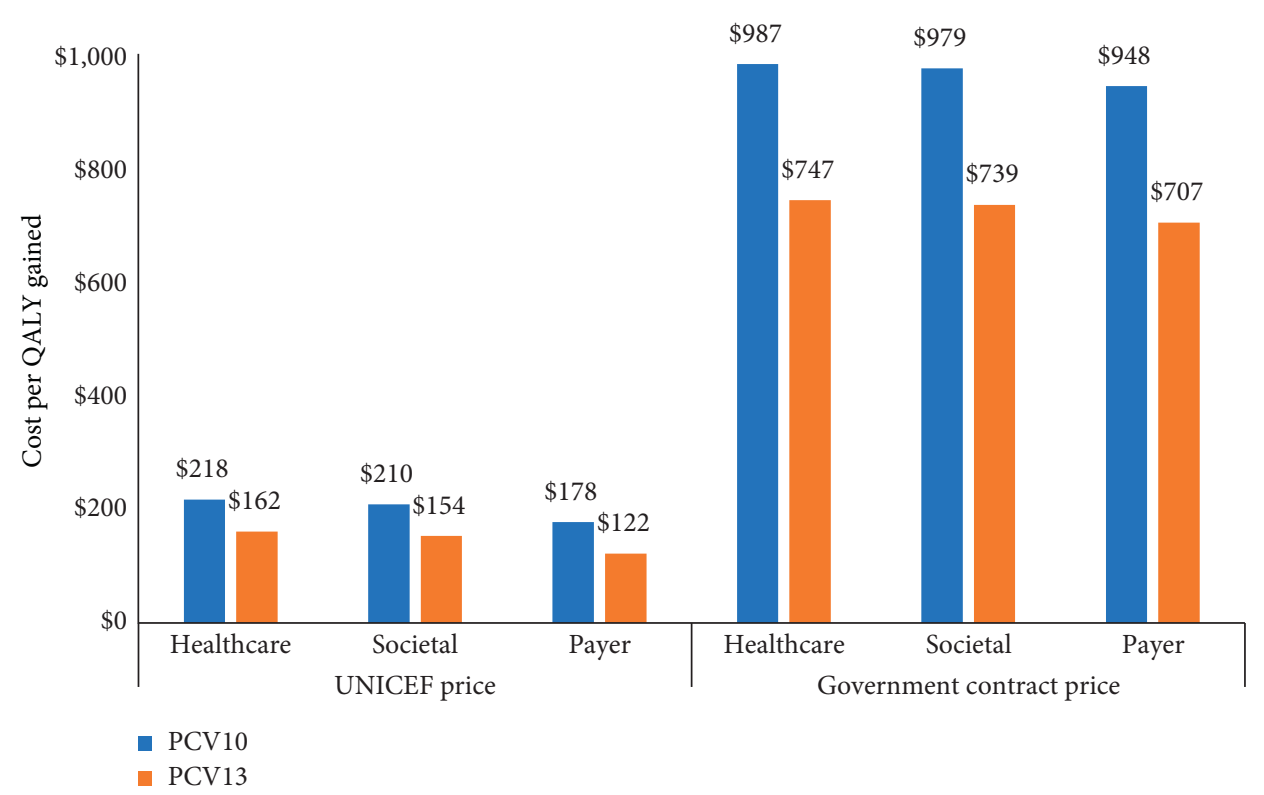

(a)

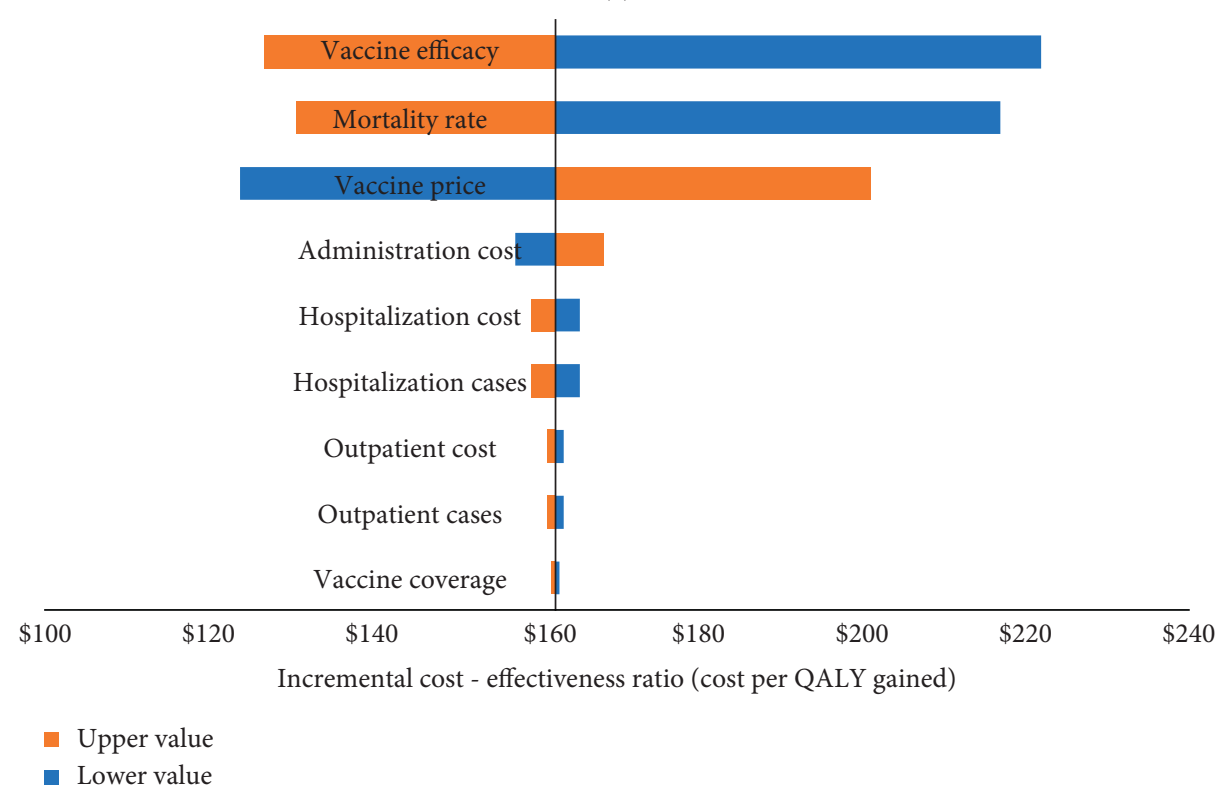

(b)

Figure 3: (a) Cost-effectiveness values of pneumococcal vaccination. (b) One-way sensitivity analysis.

previous study did not apply vaccine price comparison. However, this point could be critical for the government on making decision since Indonesia is eligible to apply UNICEF price. Secondly, we adopted three perspectives in our study: the healthcare, societal, and payer perspectives. The healthcare perspective is relevant for assisting decision makers in the health sector, and the societal perspective is often preferred to reflect the full public health impact. The payer perspective, which considered all cost covered by BPJS Kesehatan, is useful to be applied because Indonesia has started to implement the National Health Security System since 2014. In the context of budget allocation, however, this issue would be crucial as the government has targeted the universal health coverage by 2020 . Thirdly, we performed an age-structured cohort model based on a decision tree by considering several specific targeted regions on introducing pneumococcal vaccine in Indonesia, which was based on the strategic plan of the $\mathrm{MoH}$ in a period of 2017-2024 that would render more precise and valid calculation. Next to cost-effectiveness analysis, this study also analysed the budget impact of vaccination by exploring affordable required budget and making comparison with routine immunization and health expenditure budget under various scenarios.

Nevertheless, several limitations were found in this study. The first and main limitation is that we used a static model rather than a dynamic model, which has the ability to incorporate the herd effect. In general, the static model tends 
TABLE 2: Budget impact analysis of PCV13 vaccination in Indonesia.

\begin{tabular}{|c|c|c|c|c|c|c|}
\hline Year & 2019 & 2020 & 2021 & 2022 & 2023 & 2024 \\
\hline Province/district & $\begin{array}{c}\text { NTB } \\
\text { Bangka } \\
\text { Belitung } \\
\text { Kota Bogor } \\
\text { Kota Bekasi } \\
\text { Kota Surabaya } \\
\text { Gresik } \\
\text { Sidoarjo }\end{array}$ & $\begin{array}{c}\text { NTB } \\
\text { Bangka } \\
\text { Belitung } \\
\text { DKI Jakarta } \\
\text { Jawa Barat } \\
\text { Jawa Timur }\end{array}$ & Indonesia & Indonesia & Indonesia & Indonesia \\
\hline Total provinces & 4 & 5 & 34 & 34 & 34 & 34 \\
\hline Total districts & 22 & 88 & 514 & 514 & 514 & 514 \\
\hline Total birth cohort & 399,146 & $1,723,600$ & $4,712,500$ & $4,678,300$ & $4,638,200$ & $4,600,600$ \\
\hline Total targeted population* & 374,866 & $1,618,753$ & $4,425,837$ & $4,393,718$ & $4,356,057$ & $4,323,518$ \\
\hline Total number of vaccine required ${ }^{* *}$ & $1,180,828$ & $5,099,072$ & $13,941,387$ & $13,840,212$ & $13,721,580$ & $13,619,082$ \\
\hline Total introduction cost of PCV13*** & $\$ 198,211$ & $\$ 733,378$ & $\$ 4,187,641$ & $\$ 4,187,641$ & $\$ 4,196,448$ & $\$ 4,195,405$ \\
\hline Introduction cost of PCV13 per child & \multicolumn{6}{|c|}{$\$ 0.91$} \\
\hline Total national healthcare budget & $\$ 4,439,025,459$ & $\$ 4,502,303,273$ & $\$ 4,566,483,106$ & $\$ 4,631,577,814$ & $\$ 4,697,600,441$ & $\$ 4,764,564,213$ \\
\hline Total routine immunization budget & $\$ 377,811,070$ & $\$ 374,478,982$ & $\$ 539,164,943$ & $\$ 523,553,250$ & $\$ 574,860,622$ & $\$ 574,349,928$ \\
\hline \multicolumn{7}{|l|}{ UNICEF price ${ }^{* * * *}$} \\
\hline $\begin{array}{l}\text { Total vaccination cost of PCV13 } \\
\text { Vaccination cost per child ( } 3 \text { doses) }\end{array}$ & $\$ 5,378,643$ & $\$ 21,880,629$ & $\begin{array}{r}\$ 75,006,787 \\
\$ 16 .\end{array}$ & $61 \$$ & $\$ 73,824,193$ & $\$ 73,272,738$ \\
\hline $\begin{array}{l}\text { Total vaccination cost of PCV13, } \\
\text { compared with healthcare budget (\%) }\end{array}$ & $0.12 \%$ & $0.49 \%$ & $1.64 \%$ & $1.61 \%$ & $1.57 \%$ & $1.54 \%$ \\
\hline $\begin{array}{l}\text { Total vaccination cost of PCV13, } \\
\text { compared with routine } \\
\text { immunization budget (\%) }\end{array}$ & $1.42 \%$ & $5.84 \%$ & $13.91 \%$ & $14.22 \%$ & $12.84 \%$ & $12.76 \%$ \\
\hline \multicolumn{5}{|l|}{$\begin{array}{l}\text { 1mmunization budget (\%) } \\
\text { Government contract price }\end{array}$} & & \\
\hline Total vaccination cost of PCV13 & $\$ 22,317,647$ & $\$ 96,372,460$ & $\$ 263,492,206$ & $\$ 261,580,001$ & $\$ 259,337,855$ & $\$ 257,400,644$ \\
\hline Vaccination cost per child ( 3 doses) & \multicolumn{6}{|c|}{$\$ 59.54$} \\
\hline $\begin{array}{l}\text { Total vaccination cost of PCV13, } \\
\text { compared with healthcare budget (\%) }\end{array}$ & $0.50 \%$ & $2.14 \%$ & $5.77 \%$ & $5.65 \%$ & $5.52 \%$ & $5.40 \%$ \\
\hline $\begin{array}{l}\text { Total vaccination cost of PCV13, } \\
\text { compared with routine } \\
\text { immunization budget (\%) }\end{array}$ & $5.91 \%$ & $25.74 \%$ & $48.87 \%$ & $49.96 \%$ & $45.11 \%$ & $44.82 \%$ \\
\hline
\end{tabular}

${ }^{*}$ Surviving infant $\mathrm{x}$ vaccination coverage, ${ }^{* *} 3$ doses of vaccine required + buffer stock $(5 \%),{ }^{* * *}$ including social mobilization/IEC, microplanning, training, supervision, and monitoring, ${ }^{* * * *}$ vaccine price $(\$ 3,31$-dose; $\$ 2,95$ 4-dose nationwide) + tax (10\%) + import duty $(5 \%)+$ forwarder $(2,5 \%)+$ distribution $(12 \%)+$ wastage cost (25\% for 4 -dose presentation), ${ }^{* * * *}$ according to government contract in 2017 , district, province, and national.

to overestimate the cost-effectiveness result. Notably, there would be even more favourable cost-effectiveness if we took herd effect into account. Next to the ability to incorporate the epidemiology of PD and the development of herd effect, the disadvantage of a dynamic model is the requirement for data, which are currently scarce in Indonesia. Particularly, the age-specific force of infection is difficult to be estimated since it requires serial seroprevalence data and social contact data. The second limitation is the lack of vaccine effectiveness data for both vaccines, which is specific for Indonesia. To overcome this limitation, we estimated direct effectiveness of PCV13 by considering direct effectiveness of PCV13 in Malaysia and serotype coverage of PCV13 in Malaysia and in Indonesia. A similar approach was also applied to estimate direct effectiveness of PCV10.

This study aimed to provide information for policy makers in Indonesia to justify full inclusion of pneumococcal vaccination into the NIP. This study estimated the introduction cost of PCV13 would be $\$ 0.91$ per child. The vaccination cost of PCV13 per child (3 doses) was estimated to be $\$ 16.61$ and $\$ 59.54$ with UNICEF and government contract prices, respectively. Since Indonesia has graduated from Gavi, the vaccine alliance, those budgets seem overburden for a country that spends approximately $\$ 500$ million for routine immunization programs, annually. Implementation of nationwide vaccination would require approximately $\$ 257.4-\$ 263.5$ million (45-50\% of routine immunization budget) and \$73.3-\$75.0 million (13-14\% of routine immunization budget) with government contract and UNICEF prices, respectively. Comparing with national healthcare budget, the total vaccination cost of PCV13 would be approximately $5 \%$ and $2 \%$ of total health expenditure with both prices, respectively. As a country with relatively limited immunization budget, this situation would be very challenging to be sustainably implemented since more new vaccines are coming in the future. However, creating new fiscal space to finance new vaccination programs is very important to ensure the sustainability of such new additional programs so that they would be financed over the medium and long term and in a way that would not endanger the sustainability of the Indonesian government's financial position. New fiscal space for pneumococcal 
vaccination could be created from efficiency gains in other health interventions, other vaccination programs, and from the pneumococcal vaccination program itself. Expanding fiscal space could also be derived through new government financing from new revenue sources or from increased revenues, such as through economic growth, new tax administration, and strengthened macroeconomic policies [58-60]. Hopefully, this study would assist the Indonesian government in making regulation to reduce pneumococcal infection in Indonesia, which is in line with the WHO's goal on the implementation of universal vaccination.

\section{Conclusions}

Pneumococcal vaccination would be a highly cost-effective intervention to be implemented in Indonesia. Nevertheless, applying PCV13 with UNICEF price would give the best cost-effectiveness value and biggest budget impact on the routine immunization budget.

\section{Data Availability}

Datasets used and/or analysed during the current study are available from the corresponding author upon reasonable request.

\section{Conflicts of Interest}

The authors declare that there are no conflicts of interest regarding the publication of this paper.

\section{Acknowledgments}

The authors acknowledge the committee of International Health Economics Association (IHEA) Congress 2019 for the initial and shorter version of this manuscript to be presented on the poster presentation session. This study was funded by Clinton Health Access Initiative, Indonesia.

\section{References}

[1] Y. Li, Z. An, D. Yin et al., "Disease burden of community acquired pneumonia among children under 5 y old in China: a population based survey," Human Vaccines \& Immunotherapeutics, vol. 13, no. 7, pp. 1681-1687, 2017.

[2] WHO. Pneumonia fact sheet. http://www.who.int/mediacentre/ factsheets/fs331/en/.

[3] M. Hussain, A. Melegaro, R. G. Pebody et al., "A longitudinal household study of Streptococcus pneumoniae nasopharyngeal carriage in a UK setting," Epidemiology and Infection, vol. 133, no. 5, pp. 891-898, 2005.

[4] D. Bogaert, R. De Groot, and P. Hermans, "Streptococcus pneumoniae colonisation: the key to pneumococcal disease," The Lancet Infectious Diseases, vol. 4, no. 3, pp. 144-154, 2004.

[5] D. R. Feikin, L. L. Hammitt, D. R. Murdoch, K. L. O’Brien, and J. A. G. Scott, "The enduring challenge of determining pneumonia etiology in children: considerations for future research priorities," Clinical Infectious Diseases, vol. 64, no. 3, pp. S188-S196, 2017.

[6] N. Maimaiti, Z. Ahmed, Z. Md Isa, H. F. Ghazi, and S. Aljunid, "Clinical burden of invasive pneumococcal disease in selected developing countries," Value in Health Regional Issues, vol. 2, no. 2, pp. 259-263, 2013.

[7] Y.-C. Ho, P.-L. Lee, Y.-C. Wang, S.-C. Chen, and K.-T. Chen, "The economic burden of childhood invasive pneumococcal diseases and pneumonia in Taiwan: implications for a pneumococcal vaccination program," Human Vaccines \& Immunotherapeutics, vol. 11, no. 5, pp. 1081-1087, 2015.

[8] B. Fireman, S. B. Black, H. R. Shinefield, J. Lee, E. Lewis, and P. Ray, "Impact of the pneumococcal conjugate vaccine on otitis media," The Pediatric Infectious Disease Journal, vol. 22, no. 1, pp. 10-16, 2003.

[9] N. Zakiyah, W. N. Insani, A. A. Suwantika, J. van der Schans, and M. J. Postma, "Pneumococcal vaccination for children in asian countries: a systematic review of economic evaluation studies," Vaccines, vol. 8, no. 3, p. 426, 2020.

[10] M. C. Nunes and S. A. Madhi, "Review on the immunogenicity and safety of PCV-13 in infants and toddlers," Expert Rev Vaccines, vol. 10, no. 7, pp. 1-16, 2011.

[11] T. Vesikari, J. Wysocki, B. Chevallier et al., "Immunogenicity of the 10-valent pneumococcal non-typeable haemophilus influenzae protein $\mathrm{D}$ conjugate vaccine (PHiD-CV) compared to the licensed 7vCRM vaccine," Pediatric Infectious Disease Journal, vol. 28, no. 4, pp. S66-S76, 2009.

[12] World Health Organization, "Pneumococcal vaccines. WHO position paper - 2012," Weekly Epidemiological Record (WER), vol. 87, no. 14, pp. 129-144, 2012.

[13] I. Rudan, K. L. O’Brien, H. Nair et al., "Epidemiology and etiology of childhood pneumonia in 2010: estimates of incidence, severe morbidity, mortality, underlying risk factors and causative pathogens for 192 countries," Journal of Global Health, vol. 3, no. 1, Article ID 010401, 2013.

[14] R. Kumar, N. Arora, and M. Santosham, "South Asia symposium on pneumococcal disease and the promise of vaccines meeting report," Vaccine, vol. 34, no. 23, pp. 2622-2626, 2016.

[15] C.-F. Le, J. M. Jefferies, M. Y. M. Yusof, S. D. Sekaran, and S. C. Clarke, "The epidemiology of pneumococcal carriage and infections in Malaysia," Expert Review of Anti-infective Therapy, vol. 10, no. 6, pp. 707-719, 2012.

[16] M. Shiragami, A. Mizukami, O. Leeuwenkamp et al., "Costeffectiveness evaluation of the 10 -valent pneumococcal nontypeable Haemophilus influenzae protein D conjugate vaccine and 13-valent pneumococcal vaccine in Japanese children," Infectious Diseases and Therapy, vol. 4, no. 1, pp. 93-112, 2015.

[17] Ministry of Health Republic Indonesia, "PCV vaccination to be piloted in lombok," 2017, https://sehatnegeriku.kemkes.go. $\mathrm{id} /$ baca/rilis-media/20171003/1323208/imunisasi-pcv-dicanangkanlombok/.

[18] L. H. De Oliveira, L. A. Camacho, E. S. Coutinho et al., "Impact and effectiveness of 10 and 13-valent pneumococcal conjugate vaccines on hospitalization and mortality in children aged less than 5 Years in Latin American countries: a systematic review," PLoS One, vol. 11, no. 12, Article ID e0166736, 2016.

[19] C. D. C. About, "Pneumococcal vaccines," 2017, https://www. cdc.gov/vaccines/vpd/pneumo/hcp/about-vaccine.html\#:\%7E: text $=45.0 \% 25 \% 20$ efficacy $\% 20$ against $\% 20$ vaccine $\% 2$ Dtype,type $\% 20$ invasive $\% 20$ pneumococcal $\% 20$ disease $\% 20$.

[20] C. L. F. Walker, I. Rudan, L. Liu et al., "Global burden of childhood pneumonia and diarrhoea," The Lancet, vol. 381, no. 9875 , pp. 1405-1416, 2013.

[21] K. L. O'Brien, L. J. Wolfson, J. P. Watt et al., "Burden of disease caused by Streptococcus pneumoniae in children 
younger than 5 years: global estimates," Lancet, vol. 12, pp. 893-902, 2009.

[22] Unicef, "Committing to child survival: a promise renewed (Progress Report 2014)," Unicef, New York, NY, USA, 2014, http://files.unicef.org/publications/files/APR_2014_web_15Sept14. pdf.

[23] Ministry of Health, Republic of Indonesia. Indonesia Health Profile 2016. http://www.depkes.go.id/resources/download/ pusdatin/profil-kesehatan-indonesia/Profil-Kesehatan-Indonesia2016.pdf.

[24] Statistics Indonesia. Projected Population in Indonesia (20102035). https://www.bps.go.id/publication/2013/10/07/ 053d25bed2e4d62aab3346ec/proyeksi-penduduk-indonesia-20102035.html.

[25] E. M. Dunne, C. Murad, S. Sudigdoadi et al., "Carriage of Streptococcus pneumoniae, Haemophilus influenzae, Moraxella catarrhalis, and Staphylococcus aureus in Indonesian children: a cross-sectional study," PLoS One, vol. 13, no. 4, Article ID e0195098, 2018.

[26] D. B.-C. Wu, C. Roberts, V. W. Y. Lee et al., "Cost-effectiveness analysis of infant universal routine pneumococcal vaccination in Malaysia and Hong Kong," Human Vaccines \& Immunotherapeutics, vol. 12, no. 2, pp. 403-416, 2016.

[27] E. Jauneikaite, J. M. Jefferies, M. L. Hibberd, and S. C. Clarke, "Prevalence of Streptococcus pneumoniae serotypes causing invasive and non-invasive disease in South East Asia: a review," Vaccine, vol. 30, no. 24, pp. 3503-3514, 2012.

[28] D. Safari, N. Kurniati, L. Waslia et al., "Serotype distribution and antibiotic susceptibility of Streptococcus pneumoniae strains carried by children infected with human immunodeficiency virus," PLoS One, vol. 9, no. 10, Article ID e110526, 2014.

[29] T. E. Hirose, E. M. C. P. Maluf, and C. O. Rodrigues, "Pneumococcal meningitis: epidemiological profile pre- and post-introduction of the pneumococcal 10-valent conjugate vaccine," Jornal de Pediatria, vol. 91, no. 2, pp. 130-135, 2015.

[30] Indonesian Technical Advisory Group on Immunization. Pneumococcus Vaccine Recommendation. 26 January 2017 (Official Letter).

[31] N. M. A'la, A. U. Suardi, and D. K. Turbawati, "Impact of comorbidity on length of stay of hospitalized pneumonia in children," Academy of Management Journal, vol. 4, no. 1, 2017.

[32] D. Walters, S. Horton, A. Y. M. Siregar et al., "The cost of not breastfeeding in Southeast Asia," Health Policy and Planning, vol. 31, no. 8, pp. 1107-1116, 2016.

[33] P. Le, U. K. Griffiths, D. D. Anh et al., "The economic burden of pneumonia and meningitis among children less than five years old in Hanoi, Vietnam," Tropical Medicine \& International Health, vol. 19, no. 11, pp. 1321-1327, 2014.

[34] S. Zhang, P. M. Sammon, I. King et al., "Cost of management of severe pneumonia in young children: systematic analysis," Journal of Global Health, vol. 6, no. 1, Article ID 010408, 2016.

[35] Ministry of Health, "Republic of Indonesia. Peraturan menteri kesehatan RI No 52 tahun 2016 tentang standar tarif pelayanan kesehatan dalam penyelenggaraan pogram jaminan kesehatan," 2016, http://hukor.depkes.go.id/uploads/produk_ hukum/PMK_No._52_Tahun_2016_Tentang_Standar_Tarif_ Pelayanan_Kesehatan_Dalam_Penyelenggaraan_JKN_.pdf.

[36] World Health Organization, Vaccine pricing: Gavi transitioning countries, World Health Organization, Geneva, Switzerland, 2016, http://www.who.int/immunization/ programmes_systems/procurement/v3p/platform/module2/ Factsheet_vacc_pricing_Gavi_transitioning_2017.pdf.
[37] A. A. Suwantika, H. A. T. Tu, and M. J. Postma, "Cost-effectiveness of rotavirus immunization in Indonesia: taking breastfeeding patterns into account," Vaccine, vol. 31, no. 32, pp. 3300-3307, 2013.

[38] World Bank, "PPP conversion factor," 2018, https://data. worldbank.org/indicator/PA.NUS.PPP.

[39] World Health Organization, WHO Guide for Standardization of Economic Evaluations of Immunization Programmes, World Health Organization, Geneva, Switzerland, 2008, http://apps. who.int/iris/bitstream/handle/10665/69981/WHO_IVB_08. 14_eng.pdf.

[40] International Monetary Fund. GDP Per Capita. http://www. imf.org/external/datamapper/NGDPDPC@WEO/OEMDC/ ADVEC/WEOWORLD/IDN.

[41] X.-H. Zhang, O. Leeuwenkamp, K.-B. Oh, Y. E. Lee, and C.-M. Kim, "Cost-effectiveness analysis of infant pneumococcal vaccination with $\mathrm{PHiD}-\mathrm{CV}$ in Korea," Human Vaccines \& Immunotherapeutics, vol. 14, no. 1, pp. 85-94, 2018.

[42] X.-H. Zhang, M. C. Nievera, J. Carlos et al., "Cost-effectiveness analysis of pneumococcal vaccination with the pneumococcal polysaccharide NTHi protein D conjugate vaccine in the Philippines," Value in Health Regional Issues, vol. 3, no. 1, pp. 156-166, 2014.

[43] D. B. C. Wu, C. J. Chang, Y. C. Huang et al., "Cost-effectiveness analysis of pneumococcal conjugate vaccine in Taiwan: a transmission dynamic modeling approach," Value Health, vol. 15, no. 1 Suppl, pp. S15-S19, 2012.

[44] X. J. Wang, A. Saha, and X.-H. Zhang, "Cost-effectiveness analysis of a universal mass vaccination program with a PHiD-CV 2+1 schedule in Malaysia," Cost Effectiveness and Resource Allocation, vol. 15, no. 1, pp. 1-13, 2017.

[45] N. Sundaram, C. Chen, J. Yoong et al., "Cost-effectiveness of 13-valent pneumococcal conjugate vaccination in Mongolia," Vaccine, vol. 35, no. 7, pp. 1055-1063, 2017.

[46] H. S. Sohn, D.-C. Suh, E. Jang, and J.-W. Kwon, "Economic evaluation of childhood 7-valent pneumococcal conjugate vaccination in Korea," Journal of Managed Care Pharmacy, vol. 16, no. 1, pp. 32-45, 2010.

[47] W. Kulpeng, P. Leelahavarong, W. Rattanavipapong et al., "Cost-utility analysis of 10- and 13-valent pneumococcal conjugate vaccines: protection at what price in the Thai context?” Vaccine, vol. 31, no. 26, pp. 2839-2847, 2013.

[48] X. Mo, R. Gai Tobe, X. Liu, and R. Mori, "Cost-effectiveness and health benefits of pediatric 23-valent pneumococcal polysaccharide vaccine, 7-valent pneumococcal conjugate vaccine and forecasting 13-valent pneumococcal conjugate vaccine in China," Pediatric Infectious Disease Journal, vol. 35, no. 11, pp. e353-e361, 2016.

[49] K. A. Maurer, H.-F. Chen, A. L. Wagner et al., "Cost-effectiveness analysis of pneumococcal vaccination for infants in China," Vaccine, vol. 34, no. 50, pp. 6343-6349, 2016.

[50] D. B. C. Wu, F. Rinaldi, Y. C. Huang, J. A. Chang, and C. J. Chang, "Economic evaluation of universal 7-valent pneumococcal conjugate vaccination in Taiwan: a cost-effectiveness analysis," Journal of the Formosan Medical Association, vol. 112, no. 3, pp. 151-160, 2013.

[51] K. K. C. Lee, D. B. Chia Wu, O. Topachevskyi, E. Delgleize, and R. DeAntonio, "The health economic impact of universal infant vaccination with the 10 -valent pneumococcal nontypeable haemophilus influenzae protein $d$ conjugate vaccine as compared with 13-valent pneumococcal conjugate vaccine in Hong Kong," Value in Health Regional Issues, vol. 2, no. 1, pp. 64-74, 2013. 
[52] K. K. C. Lee, F. Rinaldi, M. K. U. Chan et al., "Economic evaluation of universal infant vaccination with $7 \mathrm{vPCV}$ in Hong Kong," Value in Health, vol. 12, no. 3, pp. S42-S48, 2009.

[53] S. Hu, Q. Shi, S. Song et al., "Estimating the cost-effectiveness of the 7-valent pneumococcal conjugate vaccine in Shanghai, China," Value in Health Regional Issues, vol. 3, no. 1, pp. 197-204, 2014.

[54] M. A. Haasis, J. A. Ceria, W. Kulpeng, Y. Teerawattananon, and M. Alejandria, "Do pneumococcal conjugate vaccines represent good value for money in a lower-middle income country? A cost-utility analysis in the Philippines," PLoS One, vol. 10, no. 7, Article ID e0131156, 2015.

[55] D. Che, H. Zhou, J. He, and B. Wu, "Modeling the impact of the 7 -valent pneumococcal conjugate vaccine in Chinese infants: an economic analysis of a compulsory vaccination," BMC Health Services Research, vol. 14, no. 1, pp. 1-14, 2014.

[56] R. Caldwell, C. S. Roberts, Z. An, C.-I. Chen, and B. Wang, "The health and economic impact of vaccination with 7-valent pneumococcal vaccine (PCV7) during an annual influenza epidemic and influenza pandemic in China," BMC Infectious Diseases, vol. 15, no. 1, p. 284, 2015.

[57] S. Aljunid, N. Maimaiti, Z. Ahmed et al., "Economic impact of pneumococcal protein-D conjugate vaccine (PHiD-CV) on the Malaysian national immunization programme," Value in Health Regional Issues, vol. 3, no. 1, pp. 146-155, 2014.

[58] A. A. Suwantika, N. Zakiyah, K. Lestari, and M. J. Postma, "Accelerating the introduction of rotavirus immunization in Indonesia," Expert Review of Vaccines, vol. 13, no. 4, pp. 463-472, 2014.

[59] W. Supadmi, A. A. Suwantika, D. A. Perwitasari, and R. Abdulah, "Economic evaluations of dengue vaccination in the southeast Asia region: evidence from a systematic review," Value in Health Regional Issues, vol. 18, pp. 132-144, 2019.

[60] A. A. Suwantika, N. Zakiyah, A. S. W. Kusuma, R. Abdulah, and M. J. Postma, "Impact of switch options on the economics of pneumococcal conjugate vaccine (PCV) introduction in Indonesia," Vaccines, vol. 8, no. 2, p. 233, 2020. 